\title{
Use of COVID-19 as an Illegitimate Excuse, or as a Scape-Goat
}

\section{Uso da COVID-19 como Desculpa llegítima ou como Bode Expiatório}

Jaime A. Teixeira da Silva ${ }^{1}$

\section{Dear Gazeta Médica Editors,}

The SARS-CoV-2 virus, which induced the respiratory coronavirus disease 2019 (COVID-19) pandemic, has already claimed (November 6, 2020) over 1.2 million lives and infected over 48.5 million people globally. ${ }^{1}$ Societies, economies and personal lives may be affected for years to come, either directly, as a possible yearly resurgence, even with a vaccine, similar to seasonal influenza, as vestigial left-over health ("long COVID"2), or as long-term psycho-sociological effects. ${ }^{3}$

Naturally, and it goes without saying, that those that are directly affected by COVID-19, even those recovering from it and suffering secondary and continued symptoms, have the most valid excuse (practical, psychological, moral, etc.) to "use" COVID-19 as an excuse, for example, not to be positive or participatory, or not to fulfill or complete a task or responsibility such as work. These individuals need the constant support of health care systems and society.

Yet, one must be aware of, and reproach, those who abuse COVID-19 to justify their own selfish needs, even as countless others around them suffer. We ought to be aware of those who use COVID-19, even if it does not affect them, i.e., the "onlookers"), ${ }^{4}$ as an excuse. This selfish lack of empathy that Bramble 4 refers to in "onlookers" is a different category of society that is aware of the pain and suffering of others but is either unable or unwilling to empathize with their struggle. Even if such individuals pursue a selfish personal agenda, almost impassive of the suffering of others, and even if we might 
disagree with their way of life and/or thinking, we are not in a position to judge their selfishness, and it would be unwise to morally judge their inability to suffer alongside others' suffering. They are human, after all, not saints.

However, the individuals that do merit being called out, and even investigated, are those that are using COVID-19 to abuse others, or their frailty, such as medical (and other, e.g., insurance) scammers, tricksters and frauds, the most evident being through cybercrime. ${ }^{5}$ There are also those who are being discriminated against, ${ }^{6}$ and those trapped by digital inequality. ${ }^{7}$ In addition to these blatant cases of the abuse of COVID-19 for selfish purposes are those that use the disease, or the pandemic, to obtain personal freedoms or gains (financial, or other, such as time, benefits, perks, etc.) based on false pretenses and excuses.

I believe that the following excuses of COVID-19 by "onlookers" and others not directly impacted by this coronavirus are illegitimate excuses: 1) to be lazy, procrastinate, or lie; 2) to obtain undeserving rewards (e.g., holidays, sick leave, exclusive travel, extended holiday, work from home, or exemption from tasks or duties). There may be other reasons why COVID-19 has, is, or will be used as an "excuse", and these will likely become evident over time as academics and media record personal experiences from around the globe. One case, a retraction from the journal Science, assigned disorganization and miscommunication of the research team to fatal errors, in part caused or influenced by the pandemic, that led to the paper's retraction. ${ }^{8}$

In a system ridden with weaknesses caused by $\mathrm{CO}$ VID-19 and failures to respond adequately to the pandemic, and where humanity finds itself in a state of insecurity and frailty, it may be difficult to detect such abusive individuals, or only long after the abuse has taken place and the damage, direct or secondary, has been done.

\section{RESPONSABILIDADESÉTICAS}

CONFLITOS DE INTERESSE: Os autores declaram não possuir conflitos de interesse.

SUPORTE FINANCEIRO: O presente trabalho não foi suportado por nenhum subsídio ou bolsa.

PROVENIÊNCIA E REVISÃO POR PARES: Não comissionado; revisão externa por pares.

\section{ETHICAL DISCLOSURES}

CONFLICTS OF INTEREST: The authors have no conflicts of interest to declare.

FINANCIAL SUPPORT: This work has not received any contribution grant or scholarship.

PROVENANCE AND PEER REVIEW: Not commissioned; externally peer reviewed.

\section{REFERENCES}

1. John Hopkins University. Coronavirus Resource Center. [accessed November 6, 2020]. Available from: https://coronavirus.jhu.edu/map.html.

2. Mahase E. Covid-19: What do we know about "long covid"? BMJ. 2020;370:m2815. doi: 10.1136/bmj.m2815.

3. Kontoangelos K, Economou M, Papageorgiou C. Mental health effects of COVID-19 pandemia: A review of clinical and psychological traits. Psychiatry Investig. 2020;17:491-505. doi: 10.30773/pi.2020.0161

4. Bramble B. Pandemic Ethics: 8 Big Questions of COVID-19. Sydney: Bartleby Books; 2020.

5. Buil-Gil D, Miró-Llinares F, Moneva A, Kemp S, Díaz-Castaño N. Cybercrime and shifts in opportunities during COVID-19: a preliminary analysis in the UK. Eur Soc. 2020 (in press). doi: 10.1080/14616696.2020.1804973.

6. Teixeira da Silva JA. Stigmatization, discrimination, racism, injustice, and inequalities in the COVID-19 era. Int J Health Policy Manag. 2020;9:484-5. doi: 10.34172/ijhpm.2020.87.

7. Beaunoyer E, Dupéré S, Guitton MJ. COVID-19 and digital inequalities: Reciprocal impacts and mitigation strategies. Comput Human Behav. 2020;111:106424. doi: 10.1016/j. chb.2020.106424.

8. Wu Y, Zhu B, Huang M, Liu L, Shi Q, Akbar M, et al. Proton transport enabled by a field-induced metallic state in a semiconductor heterostructure. Science. 2020;369:184-8. doi: 10.1126/ science.aaz9139. Retraction in: Science. 2020;370:179. 